https://doi.org/10.31713/m1020

\title{
FEATURES OF FORMATION OF GROUNDWATER MASSES OF THE SIVERSKYI DONETS RIVER BASIN
}

\author{
Zhykalyak M.V. \\ State Regional Geological Enterprise "Donetskgeologiya", \\ Doctor of Economics, Candidate of Geological Sciences, General \\ Director, Ukraine
}

\begin{abstract}
The introduction in Ukraine in 2016 of basin integrated principles in the zoning and management of water resources of the state in accordance with the Directives of the European Union was an extremely relevant and progressive measure. However, when adopting the relevant normative acts and regulations, the Siverskodonetsk river basin was unreasonably lowered to the sub-basin of the Don River.

Geomorphological and hydrological analysis of geographical maps at a scale of 1:200000-1:500000 of the south-eastern regions of Ukraine and border regions of the Russian Federation allowed to substantiate the basin status of the Siverskyi Donets River, to allocate 17 sub-basins and and their man-made changes, as well as to offer a water monitoring system.
\end{abstract}

Keywords. River basin, groundwater, hydrogeology, paleohydrology.

\section{Introduction}

A well-known Ukrainian scientist - Academician V.I. Vernadskyi in his scientific works on the noosphere repeatedly emphasized that water on our planet is one of the minerals that has no equal in distribution, forms one of the earth's geospheres - the hydrosphere and determines all the chemistry of the earth's crust.

Long-term changes in the hydrological regime of surface and ecological-hydrogeological conditions of groundwater necessitate the development of program measures for effective management of river basins with the definition of surface water and groundwater masses within well-founded basins and sub-basins. That is, the basin of surface water and groundwater becomes the basic unit of integrated water resources management on a basin basis. This norm was introduced into the Water Code of Ukraine in 2016 (Law of Ukraine dated 04.10.2016 № 1641-VIII) for the development and implementation of river basin management plans. In addition, the Water Code of Ukraine is the central legislative act in the field of water law, taking into account the Code of Ukraine "About Subsoil" for groundwater. The harmonization of the Water Code of Ukraine 
with the requirements of Directive 2000/60 / EC in accordance with the Association Agreement between Ukraine and the European Union (EU) has also contributed to the expansion of legal regulation of water resources on a basin basis. However, in the process of implementing the OSCE project in Ukraine "Assistance to the Ministry of Ecology and Natural Resources of Ukraine in Improving Environmental Monitoring Mechanisms" the Siverskyi Donets river basin was artificially transferred to the Don river sub-basin without taking into account established hydromorphological, geomorphological, structural-tectonic, geological, hydrogeological and paleohydrological data.

In order to restore the basin status of the Siverskyi Donets River and ensure effective management of river basins and sub-basins of surface water and groundwater of the south-eastern regions of Ukraine, we will objectively consider the hydro morphological, geomorphological, paleohydrological, structural-tectonic and hydrogeological aspects of the Siverskyi Donets River and the Don River for comprehensive substantiation of groundwater sub-basins and organization of diagnostic water monitoring.

Analytical research was carried out using a wide range of general and special scientific methods, methodology of hydrogeological research, regulations of Ukraine and published geological and geographical maps.

\section{Hydrogeological Features of the Siverskodonetsk Groundwater Basin}

The Siverskyi Donets River is the main waterway of the southeastern regions of Ukraine. Together with its largest left tributary the Oskol River - it originates on the southern slope of the Middle Russian Upland (Eastern European Platform), forms the Siverskodonetsk Plain, and flows along the northern and northeastern sides of the Donetsk Ridge (Donetsk Coal Basin). At the same time, $68.7 \%$ of the length and $55 \%$ of the intake area of the Siverskyi Donets River is located in Kharkiv, Donetsk and Luhansk Regions of Ukraine.

Within the Siverskodonetsk groundwater basin in the works of previous years, according to hydrogeological zoning and geological and structural features of this area, two hydrogeological provinces 
are distinguished: Dnipro-Donetsk artesian basin and Donetsk hydrogeological folded region.

1.1. The Dnipro-Donetsk artesian basin is fully represented in Kharkiv region and occupies the north-western part of Donetsk and northern Luhansk regions.

The main aquifer of this artesian basin is a fractured zone of Upper Cretaceous deposits, and within the anticline and dome structures - aquifers of the Upper and Lower Triassic and Lower Permian and Upper Carbonic. The most common Upper Cretaceous aquifer is characterized by significant reserves of groundwater, mainly of drinking quality, and stable significant flow rates of operational water intakes (2-10 thousand $\mathrm{m}^{3} /$ day). Most water intakes are collective and consist of several production wells located along the riverbed on the floodplain and the first floodplain terrace. Therefore, as a result of intensive operation of these water intakes, depression funnels were formed, which are elongated along the river and have transverse dimensions of $2-4 \mathrm{~km}$ with a decrease in the groundwater level in the center of the funnel to $10-15 \mathrm{~km}$. During the year in the definite periods of operation of natural reserves of groundwater of alluvial sands, which are replenished during floods.

A characteristic feature of the Dnipro-Donetsk artesian basin as a whole is the extremely large depth of the zone of active and significant multi-volume water exchange - up to 800-1000 m and more.

1.2. The Donetsk hydrogeological folded region is confined to the southern and southwestern part of the Siverskodonetsk basin and covers the peripheral areas of Donbas, Bakhmut and KalmiusToretsk basins covered by Mesozoic and Cenozoic deposits, and open and semi-closed basins (covered only by Cenozoic sediments) areas of the Donetsk coal basin.

Open areas of Donbas (Central, Dolzhansko-Rovenkivskyi, partially, Bokovo-Khrustalskyi and Chystiakovo-Snizhnianskyi), where cover sediments are practically absent, are characterized by intensive hydraulic connection of groundwater and surface water and precipitation filtration. For the semi-enclosed Donbas, where Cenozoic and Quaternary deposits with a thickness of 15-40 m are developed over most of the area, the hydraulic connection of groundwater and surface water and atmospheric supply of Carbonic aquifers are complicated and significantly limited [8]. 
The highest filtration properties of Carbonic deposits of open and semi-closed areas of Donbas are characterized by the upper weathered zone of active water exchange, with thickness from 45-60 $\mathrm{m}$ in the eastern part of the Donetsk basin and up to 100-150 $\mathrm{m}$ in its western part and within zones of tectonic disturbances [6].

Mineralization of groundwater in the zone of active water exchange of open and semi-closed areas of Donbas is $0.8-1.5 \mathrm{~g} / \mathrm{dm}^{3}$, and in closed $1.5-2.2 \mathrm{~g} / \mathrm{dm}^{3}$. In the range of depths of $700-900 \mathrm{~m}$, the mineralization of carbon groundwater on average reaches $3.0-3.5 \mathrm{~g} / \mathrm{dm}^{3}$, and then for every $100 \mathrm{~m}$ increase in depth, it increases by $0.25-0.6 \mathrm{~g} / \mathrm{dm}^{3}[6]$.

The closed north-western part of the Donetsk hydrogeological folded region, which partially includes the Pokrovsk coal field and completely the Bakhmut and Kalmius-Toretsk basins, is a transitional zone between the Dnipro-Donetsk artesian basin and the typical Donetsk hydrogeological folded basin. As a result of subplatform Cimmerian and Alpine tectogenesis in this area, the north-western (transitional) part of the Donetsk hydrogeological folded region is significantly complicated by linear and downfold -like synclines (Komyshuvasko-Lymanska, KramatorskoChasivoyarska, Northern, Kryvolukska, Raisko-Kalynivska and Kurdiumivska), which are separated and articulated with linear (Main and Druzhkivsko-Kostiantynivska) anticlines and brachial uplifts - Bakhmutske, Sviatogirske, Kamianske, Slavianske, Bantyshevske and Toretske.

In general, depending on the geological and structural timing and openness of the main aquifers of the north-western part of the Donetsk hydrogeological region, the zone of active water exchange with fresh (less than $\left.1.5 \mathrm{~g} / \mathrm{dm}^{3}\right)$ and weakly brackish $\left(1.5-2.5 \mathrm{~g} / \mathrm{dm}^{3}\right)$ groundwater varies from $250-300 \mathrm{~m}$ to $700-800 \mathrm{~m}$ [6].

Unfavorable conditions of supply and water exchange in the areas of Upper Cretaceous and Triassic overlap with Quaternary and Neogene-Peleogenic deposits cause the formation of mostly weakly brackish and brackish groundwater.

\section{Geological, Paleohydrological and Geoformological Differences of the Siverskyi Donets and the Don River Basins}

The main geological and tectonic megastructures of the Siverskodonetsk river basin are the Dnipro-Donetsk Rift (DDR) and Donbas, as integral components of the united Dnipro-Donetsk 
avlacogenic depression, and the Don River basin - the Eastern European platform.

Within the Eastern European platform, the main continental watershed between the Baltic and Black Seas runs, and the Dnipro River megabasin and the Volga River megabasin are equivalent to the common continental megabasins of the Black Sea-Caspian continental slope. According to hydrological factors, the Don River basin in the border regions of the Russian Federation belongs to the Volga River megabasin, and the Siverskodonetsk basin valley of the Dnipro-Donetsk artesian basin together with the Middle Dnipro basin is part of the Dnipro megabasin (Fig. 1).

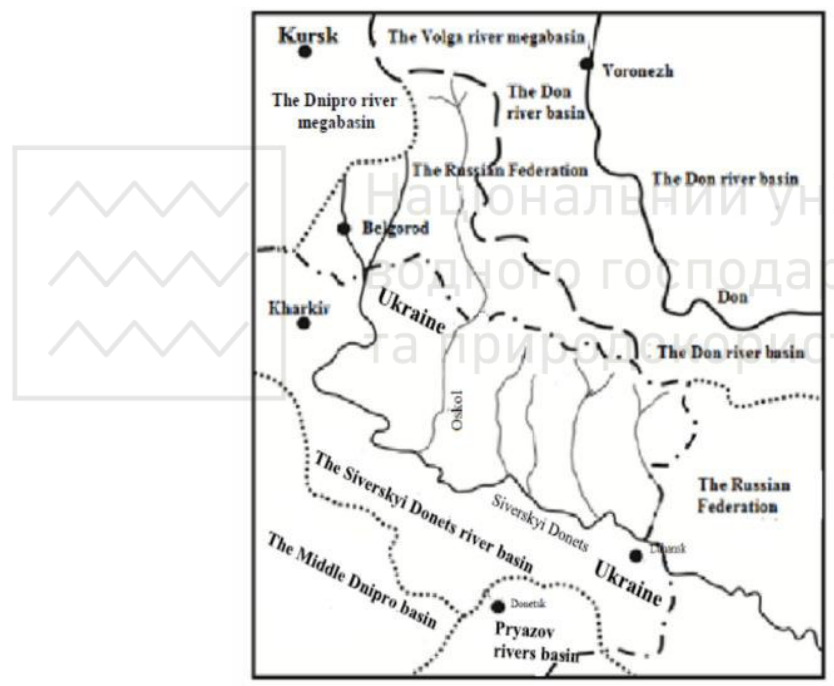

Fig. 1. Hydrographic zoning of river basins of the border regions of Ukraine and the Russian Federation

According to paleogeogeographical studies of previous years, the North Donbas Paleorica - Paleo-Donets or Pra-Donets is the largest fossil river in the Donbass, the channel valley of which is reliably isolated and well studied in the process of complex lithologic-andfacies studies of coal, Triassic Neogene and Quaternary sediments as an integral part of the watershed of the Paleo-Dnipro megabasin within the south-eastern part of the DDR and Donbas. Moreover, the 
Donetsk coal basin (Donetsk Ridge) on the initiative of a domestic scientist from Slobozhan area E.P. Kovalevskyi in 1829 received its official name from the Siverskyi Donets River, not the Don River, because the Siversky Donets River receives all tributaries from the basin catchment area, washes and enriches cracked-porous groundwater on the left bank and significantly improves the water balance of open and semi-open Donbass on the right bank [5].

In the paleogeographic development of the Paleo-Don (Miocene) and Pra-Don (Late Pleistocene) Russian scientists during many years of research have established the formation of the Paleo-Don and PraDon joint with Pra-Manych Pryazov-Don basin and a single delta of the Pra-Don. (Fig. 2, 3).

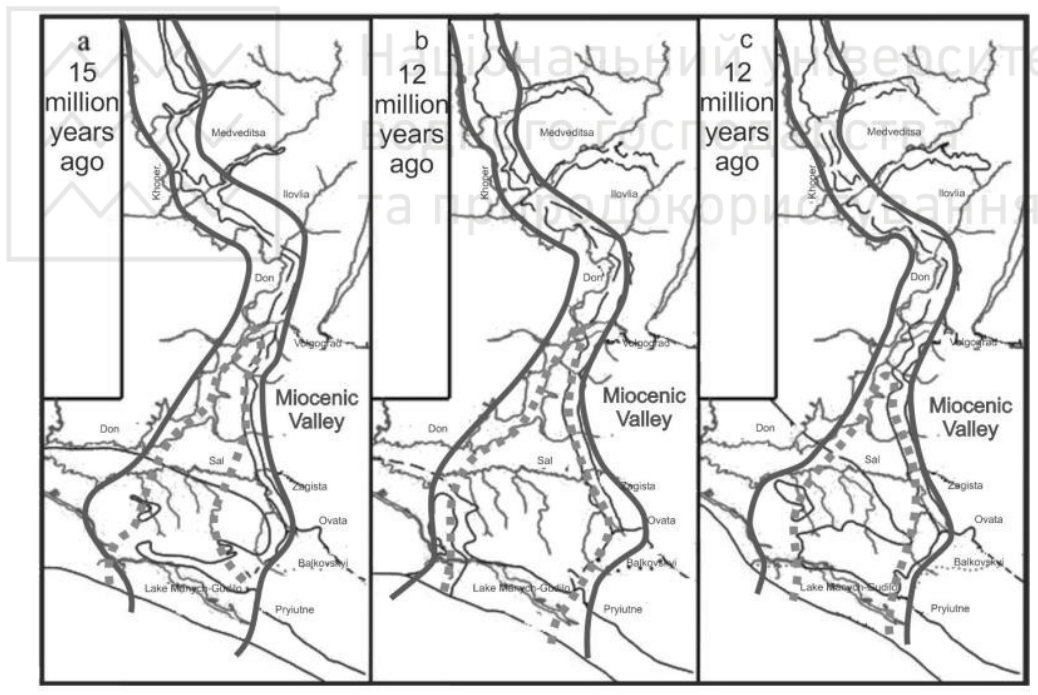

Fig. 2. Miocenic valleys of the Paleo-Don (according to M.N. Gryshchenko, 1952; A.S. Zastrozhnov, 2009; G.R. Rodzianko, 1965, 1970)

That is, Taganrog Bay then reached the meridian of the current Lake Manych [3]. However, after the Don glaciation about 600 thousand years ago and the formation of powerful moraine deposits in the Don Valley at the latitude of today's Volgograd, the course of 
the Don River changed significantly in the south-western direction and occupied the submeridional valley formed by the Siverskyi Donets River, which is confined to the south-eastern confluence of the Dnipro-Donetsk depression or the Eastern Donbas.

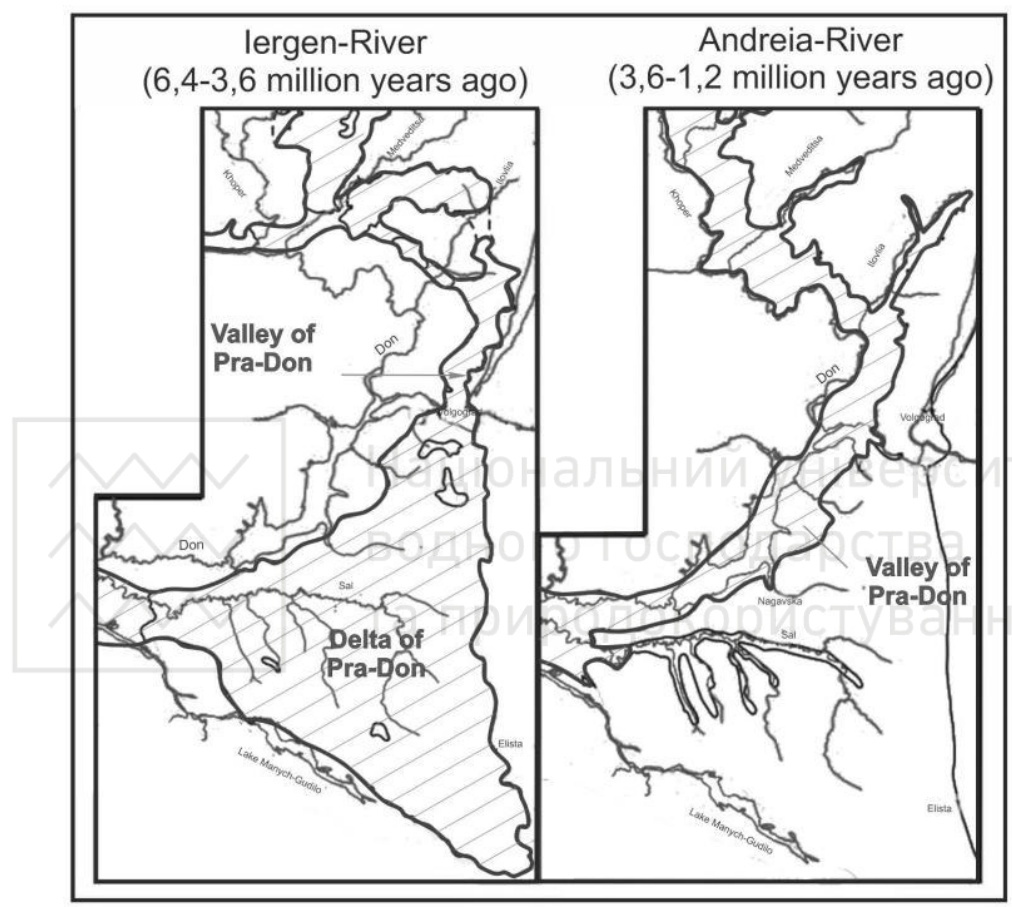

Fig. 3. The valley of the Pra-Don in the period of the Iergen River and Andeia River (M.N. Grishchenko and Y.A. Petrakovych, 1939; G.V. Kholmov, 1984)

At the same time, the independence of the Siverskyi Donets riverbed was preserved almost to the latitude of the present city of Rostov-on-Don and can be traced even now to the Taganrog Bay of the Sea of Azov called the Dry Donets River - the Aksai River - the Dead Donets River with the formation of an independent delta, separated by a strait from the delta of the Don River (Fig. 4). 


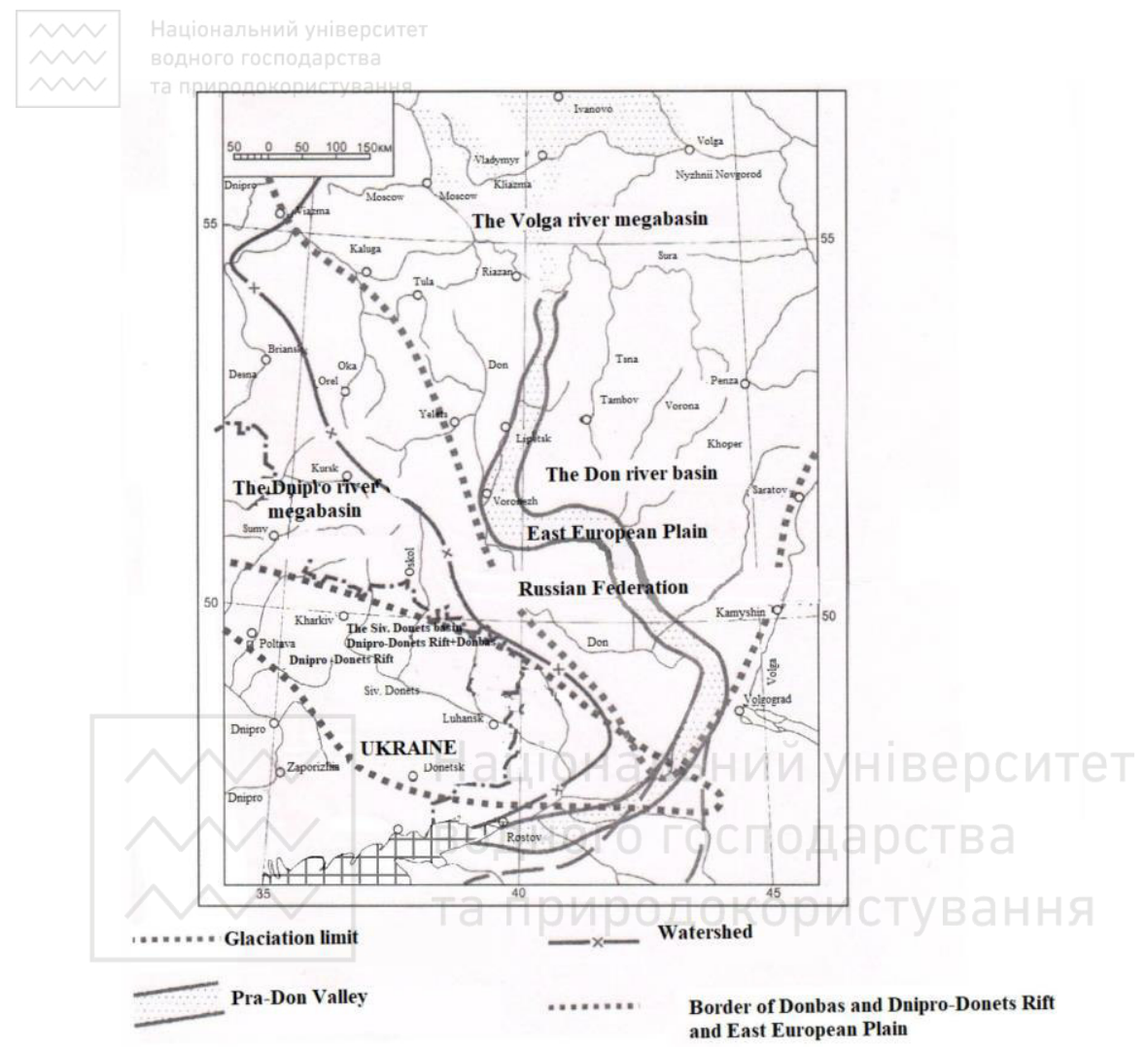

Fig. 4. Scheme of water basins in the maximum stage of glaciation between the Dnipro and Volga rivers (600 thousand years ago), according to V.A. Brymov (1984), A.S. Zastrozhnov (2009), G.I. Goretskyi (1961, 1964, 1970), M.N. Gryshchenko (1952), G.N. Rodzianko (1947, 1965, 1984)

On geographical maps of scale 1:200000-1:500000 within the Pryazov-Don lowland or the Lower Don according to geomorphological, hydrological and geological factors in Rostovregion of the Russian Federation three independent river basins of surface water and groundwater are reliably allocated: the Siverskyi Donets river basin, the Don river basin and the Pryazov rivers basin (Fig. 5).

Thus, on the territory of the south-eastern regions of Ukraine and within the border regions of the Russian Federation, the Siverskyi Donets river basin is by all signs and factors an independent river basin of both groundwater and surface water. 


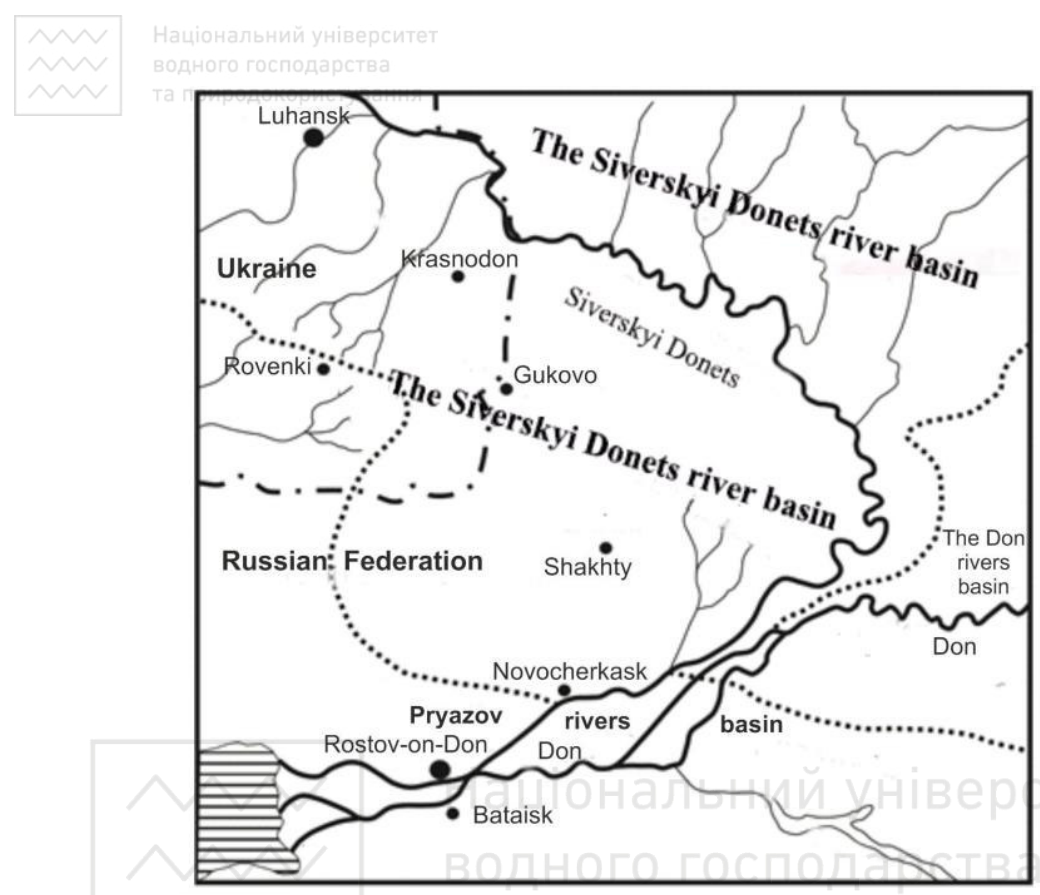

Fig. 5. Hydrographic zoning of river basins of the Lower Don

\section{Brief Description of Sub-basins of Water Basins of the South-Eastern Regions of Ukraine}

The south-eastern regions of Ukraine are represented by the Siverskodonetsk river basin, the Middle Dnipro basin of the Dnipro megabasin and the Pryazov rivers basin.

3.1. The Siverskodonetsk basin of surface and groundwater, taking into account hydrological, structural-tectonic and geologicalhydrogeological features of the river basin, is represented by subbasins of the left slope and sub-basins of the right slope (Fig. 6). 


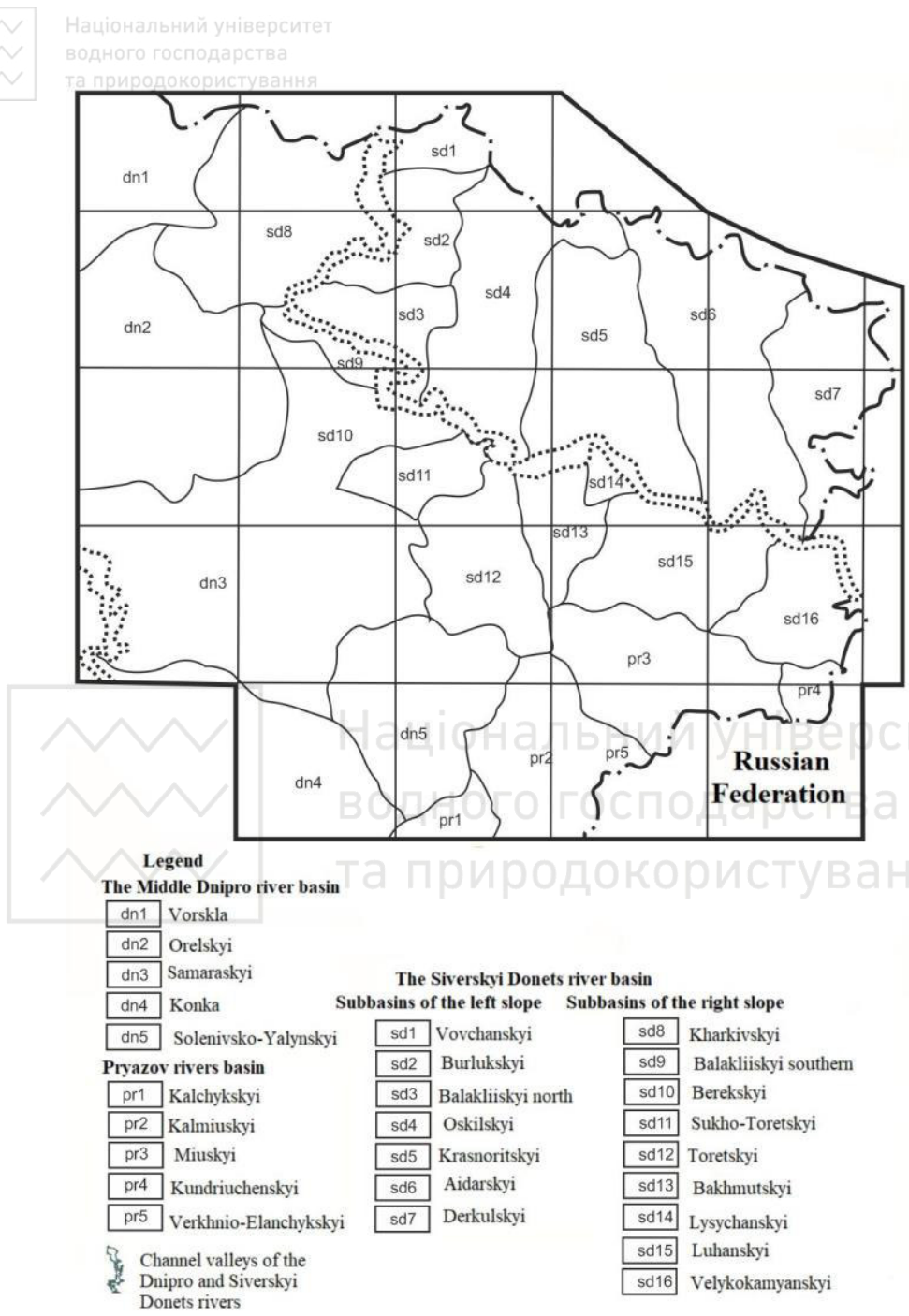

Fig. 6. Scheme of water basins and sub-basins of the south-eastern regions of Ukraine

The left slope of the Siverskyi Donets River is represented by Vovchanskyi (sd1), Burlukskyi (sd2), Pivnichno-Balakliyskyi (sd3), Oskilskyi (sd4), Krasnoritskyi (sd5), Aidarskyi (sd6) and Derkulisky (sd7) sub-basins, and the right - Kharkivskyi (sd8), South Balakliiskyi (sd9), Berekskyi (sd10), Sukho-Toretskyi (sd11), 
Toretskyi (sd12), Bakhmutskyi (sd13), Lysychanskyi (sd14) Luhanskyi (sd15), Velykokamianskyi (sd16) and Kundriuchenskyi (sd17) sub-basins (Fig. 6). Aquifers and sub-basin complexes of the Siverskodonetsk River basin are traditionally distinguished in alluvial Quaternary, Neogene, Paleogene, Cretaceous, Jurassic, Triassic, Lower Permian and coal deposits, which are separated by a number of refractories. Regionally aged refractories are associated with deposits of Lower Quaternary, Neogene and Jurassic clays, clayey marls of the Paleogene Kyivan world, massive uncracked marl-Cretaceous strata of the Upper Cretaceous, chemogenic deposits of the Lower Permian and clay-shaly layers of the Lower Permian and Carbonic.

According to long-term system studies of previous years, groundwater supply of sub-basins of the Siverskodonetsk basin is carried out by infiltration and filtration of rainwater, snow melting, condensation of water vapor and film transfer of moisture with a significant impact of unloading deep waters in tectonic and tectonic zones and also the influence of natural and man-made factors in connection with the filtration losses of open canals and water mains.

3.2. The Middle Dnipro sub-basins are represented by the the Vorskla and the Orelka rivers sub-basins typical of the DniproDonetsk Rift and the transitional sub-basins of the Samara and Konka rivers and the Solenivsko-Yalynskyi sub-basin. They are characterized mainly by medium-highly mineralized fractured waters of the Carbonic, Triassic, and Jurassic and fractured in Precambrian crystalline deposits. Weakly mineralized and fresh groundwater is associated mainly with alluvial, Neogene, and Paleogene aquifers.

3.3. The Pryazov rivers sub-basins are represented in the south of the south-eastern regions of Ukraine by small rivers from the Lower Dnipro basin to the eastern border of Ukraine. Groundwater masses are associated with Cretaceous and Cenozoic sediments (upper aquifers), which lie on the blurred surface of the Upper Paleozoic deposits and the Precambrian crystalline basement (pore-fractured and fractured horizons).

\section{General Characteristics of Groundwater Masses of the Siverskodonetsk River Basin}

Determination of geological section and pre-Quaternary surface of groundwater masses must be performed separately for each of the 
17 sub-basins of the Siverskodonetsk river basin, taking into account structural-tectonic, geological-formation and hydrogeological factors and patterns. The vast majority of sub-basins are characterized by a three-layer structure of sedimentary strata in the Upper Paleozoic, Mesozoic, and Cenozoic structural-stratigraphic complexes (layers). According to the degree of openness of the Upper Paleozoic Carboniferous and Lower Permian deposits, open, semi-open and closed sub-basins are distinguished.

All sub-basins of the left slope of the Siverskyi Donets River and the Kharkivskyi, Pivdenno-Balakliiskyi, Berekskyi and SukhoToretskyi sub-basins of the right slope are closed sub-basins. Masses of groundwater of these sub-basins are represented by the aquifer complex of the Upper Triassic and Upper Cretaceous and Alluvial, Neogene and Paleogene sands, which are characterized by weakly mineralized and fresh hydrocarbonate, rarely sulfate-hydrocarbonate waters with a salinity from $0.3-0.8 \mathrm{~g} /$ to $0-1.5 \mathrm{~g} / \mathrm{dm}^{3}[7,8]$.

Intensive manifestation in these sub-basins of Cimmerian and Alpine tectogenesis has led to the formation of brachyanticline and salt dome structures and small artesian basins in synclines and downfolds with their areas of supply, transit and groundwater discharge.

In the layered systems of small artesian basins with transitional water exchange, the processes of desulfation and cation exchange are manifested, which leads to the improvement of groundwater quality mainly of chloride-hydrocarbonate-sodium composition with mineralization from $0.2-1 \mathrm{~g} / \mathrm{dm}^{3}$ and hardness up to $7 \mathrm{mmol} / \mathrm{dm}^{3}$. However, in the watersheds in poorly permeable sediments of different ages developed processes of secondary salinization, which causes the formation of waters with increased mineralization from $1.5-3 \mathrm{~g} / \mathrm{dm}^{3}$ to $4-6 \mathrm{~g} / \mathrm{dm}^{3}$ mainly sulfate, hydrocarbonate-sulfate, sulfate-hydrocarbonate-calcium and chloride-sulfate composition [1]. In the areas of exits to the pre-Cenozoic surface of hemogenic sediments of the lower Permian within the brachyanticline and salt dome structures, groundwater mineralization increases from 2-10 g / $\mathrm{dm}^{3}$ to $50-312 \mathrm{~g} / \mathrm{dm}^{3}$ of sulfate, sulfate-chloride and chloride composition [8].

Masses of groundwater of semi-enclosed sub-basins (Bakhmutskyi, Lysychanskyi and Kundryuchenskyi sub-basins) are 
characterized by difficult conditions of formation of chemical composition of groundwater from fresh-slightly saline (0.5-1.9 $\mathrm{g} / \mathrm{dm}^{3}$ ) sulfate-hydrocarbonate and sodium-calcium to chloride and chloride -sodium with mineralization from $2 \mathrm{~g} / \mathrm{dm}^{3}$ to $7.5 \mathrm{~g} / \mathrm{dm}^{3}$ [6]. The effective thickness of aquifers varies from $5 \mathrm{~m}$ to $90 \mathrm{~m}$ and averages $40-50 \mathrm{~m}$. Carbonic aquifers are characterized by low water enrichment and water conductivity. In the valleys, the rivers are mixed with fresh groundwater of the Middle Paleogene and Alluvium.

Masses of groundwater of open sub-basins (Toretskyi, Luhanskyi and Velykokamianskyi sub-basins are represented by porousfissured, fissured and fissured karst groundwater, which in the nearsurface weathered zone, with thickness from 46-70 m to $150-200 \mathrm{~m}$, form a single aquifer). Below this zone, groundwater circulates in separate inhomogeneous aquifers, mining and man-made cavities and zones of tectonic faults with an average groundwater flow modulus of $0.5-1.51$ / sec per 1 sq. $\mathrm{m}[6]$.

The chemical composition of groundwater in the drainage zone of the river network corresponds to the general physical and geographical zoning: in the western part is dominated by hydrocarbonate-sulphate-sodium-calcium and sulphate-sodiumcalcium water with a salinity of up to $2.5-3.5 \mathrm{~g} / \mathrm{dm}^{3}$, and in the east and south-east - weakly mineralized and fresh hydrocarbonatecalcium waters [8].

\section{Regional Technogenic Changes and Organization of Diagnostic Monitoring of Groundwater}

The territory of groundwater sub-basins of the Siverskodonetsk river basin is located in different hydromorphological, geological, structural-tectonic and hydrogeological conditions, which determines the peculiarities of the formation of groundwater masses, their resource potential, quantitative and qualitative changes of aquifers and water intakes which is necessary to take into account both groundwater and surface water in the process of organizing diagnostic monitoring $[5,9]$.

Indoor sub-basins are characterized by the highest protection of groundwater masses with a low level of man-made pollution associated with local impact of industrial enterprises and excessive 
use of fresh groundwater of the Upper Cretaceous and hydraulically associated alluvial aquifers.

Intensive changes in hydrodynamic conditions and quality of groundwater masses of semi-enclosed sub-basins of the Siverskodonetsk river basin are associated with outdated environmentally unsanitary industrial production within Bakhmutskyi, Slovyansk-Kramatorskyi, Rubizhansko-Lysychanskyi, Siverodglovenskyi and Alchevsko-Luhanskyi industrial agglomerations with intensive pollution by metals, chemical compounds and industrial and household waste. However, given the significant reduction in recent years of the impact on the geological environment and groundwater of electricity, metallurgy, engineering and chemical industries, the greatest man-made impact are open subbasins of the Siverskodonetsk river basin due to low protection of groundwater from industrial impact and mass closure of coal mines.

The main criterion for the protection of aquifers of the Donbas coal seam is the presence of strong $(10-30 \mathrm{~m})$ and sustained layers of overlapping Cenozoic and Anthropogenic waterproof deposits, but the approach of mine workings to the near-surface zone in river valleys and the presence of hundreds of sloping spatial hydraulic connection of groundwater and surface water and increase the level of man-made danger in the open sub-basins of the Siverskodonetsk river basin in the conditions of mass uncontrolled closure of coal mines $[4,6]$.

Currently, about 50 mines of Donbas are considered to be flooded by two thirds of the volume of the mountain massif and in the immediate vicinity of the near-surface zone of increased fracturing. At the same time, the pace and scale of changes in the ecological and hydrogeological regime of groundwater are particularly valid and significant in the territory temporarily not controlled by Ukraine, in densely populated old industrial areas and in the demarcation zone. In particular, flooding by mine waters of the near-surface zone of Bunge (Yunkom), Horlivka, Yenakiyevo, Pervomaisk, Zolote and partially Toretsk, Makiivka and Shakhtarsk led to the restoration of hydraulic connection of surface and groundwater and the formation of stable man-made systemic restoration of historical groundwater levels $[4,6]$. 
The rise of mine water to the historical level of groundwater in areas of mass flooding of coal mines in accordance with the parabolic dependence after their rapid rise in the first 5-7 years may continue for 20-25 years from the beginning of uncontrolled flooding of mine workings depending on cyclical changes in levels and dynamic-filtration regularities of groundwater masses distribution within open and semi-open sub-basins [6].

Taking into account the above, the system of diagnostic regional and zonal monitoring of groundwater should be based on a comprehensive study of disturbed and modeling of reproducible natural regime with determination of vertical and lateral hydrogeological patterns of groundwater masses within all subbasins of the Siverskodonetsk river basin.

The Siverskodonetsk river basin management plan for groundwater should be based on the implementation of the following mandatory structural measures (stages):

- hydromorphological, geomorphological, geological and hydrogeological description of groundwater sub-basins;

- selection and typology of groundwater masses;

- characteristics of the main factors of man-made impact on the state of groundwater;

- allocation and mapping of zones of technogenic disturbed groundwater regime in zones of industrial influence;

- determination of areas of undisturbed natural groundwater regime that are subject to protection;

- modelling and organization of the system of diagnostic monitoring of groundwater masses within the sub-basins;

- implementation of socio-economic analysis of groundwater use and preparation of recommendations to improve its efficiency.

\section{Conclusions}

The analysis of hydrogeological features of the Siverskodonetsk river basin and paleohydrological differences of the Siverskyi Donets and the Don Rivers allowed to substantiate the independent basin status of the Siverskyi Donets River on the territory of the southeastern regions of Ukraine and border regions of the Russian Federation.

On the territory of Ukraine within the Siverskodonetsk river basin 17 water sub-basins have been identified and the hydrogeological 
features of groundwater masses in closed, semi-closed and open subbasins are briefly described.

In order to form a balanced environmentally friendly water management system of the Siverskodonetsk river basin, regional man-made changes in groundwater are considered and a system of diagnostic monitoring of groundwater is proposed.

After amendments to the Water Code of Ukraine dated 04.10.2016 № 1641-VIII on restoration of the basin status of the Siverskyi Donets River, it will be necessary to finalize regulations on the development of the Siverskodonetsk river basin management plan and allocation of sub-basins and groundwater and surface water.

\section{References}

1. But Yu.S., Reshetov I.K., Drobnokhod N.I. et al. (1987). Small Artesian Basins of the North-Western Donbas. - Kiev: Naukova Dumka. - 200p.

2. Vernadskyi V.I. (1936). History of Minerals of the Earth's Crust//in 2 volumes/vol. 2. History of Natural Waters. - L.: ONTI Khimteoret. - Part 1, issue 3.

3. Goretskyi G.I. (1982). Paleopotamological Sketches of Paleo-Don and ProDon. - Minsk: Nauka i Tecknika. - 248p.

4. Denisov N., Averin D., Yushchuk A. (2017). Environmental Damage Assessment and Priorities for Environmental Restoration in Eastern Ukraine. - Kyiv: BAI.T. $-88 \mathrm{p}$.

5. Zhykalyak M.V., Kuroyedova S.V., Marynchenko M.E. (2018). Harmonization of the Groundwater Monitoring System of Donbas with the Standards of the European Union. - Geoforum-2018. - Kyiv, UkrSGRI. - P. 119-124.

6. Zhykalyak M.V., Kuroyedova S.V., Marynchenko M.E. (2019). Methodical and Normative-legal Aspects of Assessment of Ecologicalhydrogeological Changes as a Result of Flooding of Donbas Coal Mines/Intern. scientific-practical conf. "Modern Problems of Mining Geology and Geoecology". SI SCMGGID NASU. Kyiv. - P. 125-133.

7. Zastezhko Yu.S. (1972). Characteristic Features of the Chemical Composition of Groundwater in the South-Eastern Part of the Dnipro-Donetsk Basin/Tr. of Ukrainian Research Institute for Natural Gases. Issue. 4. - Kharkiv. - P. 250-259.

8. Suyarko O.V. (1970). About the Connection of the Zones of Unloading of Deep Horizons of the Paleozoic with the Deep Tectonics of Donbas//Reports of AS of UkrSSR. - Ser. B. № 5. - P. 405-406.

9. Trofanchuk S.I. (2019). The First Steps in Developing a Management Plan for the River Sub-basin of the Siverskyi Donets and the Lower Don Subbasin//Vodne Gospodarstvo Ukrayiny, № 9-10. - Kyiv. - P. 9-15. 